\title{
Implementasi Utility Al untuk Pembuatan Fitur Auto-Battle pada Game Dude Knight
}

\author{
Syauqi Hidayatul Hakim ${ }^{* 1}$, Ali Sofyan Kholimi ${ }^{2}$, Lailatul Husniah ${ }^{3}$ \\ 1,2,3 Teknik Informatika/Universitas Muhammadiyah Malang \\ syauqi_437238@webmail.umm.ac.id ${ }^{* 1}$, kholimi@umm.ac.id ${ }^{2}$, husniah@umm.ac.id ${ }^{3}$
}

\begin{abstract}
Abstrak
Grinding adalah kegiatan repetitif yang dilakukan untuk meningkatkan kemampuan karakter (level) dalam game terutama dengan genre RPG. Dengan sistem seperti ini, konten game selanjutnya akan sulit diraih oleh pemain yang ingin menamatkan game tetapi tidak memiliki banyak waktu bermain. Fitur auto-battle hadir untuk mengatasi masalah tersebut. Pemain dapat melakukan hal lain selagi auto-battle berjalan untuk grinding. Fitur tersebut haruslah dilengkapi dengan kecerdasan buatan (Al) yang bisa menyelesaikan pertarungan dengan baik. Hal tersebut semakin dibutuhkan terutama pada game dengan genre turn-based strategy seperti Dude Knight dimana strategi dibutuhkan untuk menang. Meskipun game ini memiliki auto-battle bawaan dari game engine yang digunakan, terdapat beberapa kekurangan pada auto-battle bawaan tersebut. Penelitian ini menawarkan auto-battle yang lebih baik menggunakan Utility Al. Perilaku pada auto-battle yang dibuat akan difokuskan pada Al yang lebih stabil dalam memenangkan pertarungan dan dapat memenangkan pertarungan lebih cepat. Kedua Al akan diuji dan akan dilakukan t-test sebelum melakukan perbandingan data. Hasilnya adalah Utility Al memiliki rasio kemenagan yang lebih besar dari Al bawaan. Utility Al juga memenangkan pertarungan lebih cepat.
\end{abstract}

Kata Kunci: Turn-based Strategy, Auto-Battle, Utility Al, T-Test

\section{Abstract}

Grinding is a repetitive activity to increase character's power (level) in games especially in RPG genre. With this kind of system, the next content of the game will be harder to reach by players that wanted to finish the game but they don't have much time to play. Auto-battle feature came to solve that problem. Players could do something else while their games grinding using auto-battle. This feature should be equipped with an artificial intelligence (Al) that can finish a battle properly. That is even more so for turn-based strategy games like Dude Knight which require strategies to win. Although the game engine used to develop Dude Knight has built-in auto-battle, there are still some drawbacks. This research proposes a better auto-battle using Utility Al. Creating an Al with more stable win and faster win is what will be focused on. Both Al will be tested and t-test will be done before comparing the data. The results are Utility Al have higher win rate than original Al. Utility Al also win the battles faster.

Keywords: Turn-based Strategy, Auto-Battle, Utility Al, T-Test

\section{Pendahuluan}

Grinding adalah kegiatan repetitif yang dilakukan untuk meningkatkan kemampuan karakter (level) dalam game[1]. Meskipun beberapa orang menyukai kegiatan tersebut ketika bermain, pemain yang tidak memiliki banyak waktu luang namun tetap ingin bermain tidak akan merasakan hal yang sama. Pemain akan membutuhkan waktu yang lama untuk melihat konten atau cerita selanjutnya. Pada tahun 2017 sebanyak 72\% gamer atau pemain game di Amerika Serikat berusia di atas 18 tahun. Sedangkan rata-rata usia gamer adalah 35 tahun[2]. Hal ini menunjukkan bahwa banyak orang yang masih bermain game meskipun sudah memasuki usia kerja.

Dalam game, Auto-mode adalah fase ketika pemain memilih untuk memberikan kendalinya kepada Al[3]. Beberapa game menghadirkan fitur auto-battle, dimana kegiatan grinding akan diambil alih oleh Al. Sehingga pemain bisa meninggalkan game ke Al untuk melakukan pekerjaan lain. Ketika kembali, pemain akan melihat peningkatan kemampuan pada karakter game-nya. Namun kebanyakan dari game tersebut memiliki mekanisme pertarungan yang sederhana. 
Sehingga, Al untuk auto-battle juga tidak terlalu rumit. Bahkan untuk game dengan genre turnbased strategy sekalipun. Game dengan genre tersebut memiliki unsur strategi dalam memainkanya layaknya sebuah catur. Pemain harus mempertimbangkan langkah atau aksi yang akan dilakukannya di setiap giliran. Dude Knight adalah sebugh game dengan unsur RPG dan turn-based strategy. Game ini memiliki banyak parameter yang harus dipertimbangkan dalam strategi pertarungannya.

Dude Knight dibuat dengan game engine RPG Maker VX Ace. Dalam game engine tersebut terdapat fitur auto-battle bawaan. Namun fitur tersebut tidak bisa di aktifkan atau di nonaktifkan sesuai keinginan pemain layaknya fitur auto-battle pada umumnya. Al dari auto-battle bawaan tersebut hanya memilih skill atau jenis serangan yang dapat menghasilkan kerusakan terbesar pada musuh. Begitu juga dengan penyembuhan yang bisa diberikan ke karakter teman. Skill dengan kerusakan tinggi cenderung membutuhkan energi yang banyak. Jika energi tersebut habis maka karakter hanya bisa menggunakan serangan biasa. Energi pada Dude Knight disebut MP (Mana Point) dan TP (Technique Point). Dude Knight juga memiliki skill yang bisa memberikan status effect. Status effect adalah status yang dapat membahayakan penderita. Contoh status tersebut adalah racun yang bisa mengurangi darah atau nyawa $(H P)$ penderita setiap giliran. Adapula silence yang dapat membuat penderita tidak bisa menggunakan skill sihir. Status effect memiliki potensi untuk membalikkan keadaan. Status tersebut akan hilang setelah beberapa giliran telah berjalan, atau menggunakan item atau skill yang dapat menghilangkan status tertentu. Sayangnya auto-battle tidak akan menggunakan item atau skill tersebut. Kondisi Auto-Battle pada RPG Maker dan strategi bertarung pada Dude Knight yang cukup kompleks akan menyusahkan pemain yang tidak memiliki banyak waktu luang untuk grinding.

Dengan banyaknya parameter yang dimiliki game Dude Knight dalam memilih strategi, penulis mencoba menyelesaikan permasalahan tersebut dengan membuat auto-battle baru menggunakan Utility Al. Utility Al yang dikenalkan oleh Dave Mark adalah Al untuk pengambilan keputusan dan behavior yang menggunakan konsep utility atau kegunaan. Suatu benda memiliki nilai kegunaan tergantung dimana, kapan, dan bagaimana benda tersebut digunakan[4]. Begitu juga jika diterapkan pada Al pengambilan keputusan. Suatu keputusan akan sangat bermanfaat jika kondisi yang mempengaruhinya sesuai. Utility Al menghitung nilai kegunaan tiap keputusan atau aksi berdasarkan kondisi yang mempengaruhinya kemudian memilih aksi dengan nilai kegunaan terbaik. Kondisi tersebut berupa kombinasi dari kebutuhan pada saat itu dan bagaimana suatu aksi dapat memenuhi kebutuhan tersebut[5].

Pada penelitian[5][6][7], Utility Al digunakan untuk membuat suatu agen dalam suatu kondisi yang memiliki behavior layaknya manusia. Namun penelitian tersebut mengombinasikan Utility Al dengan Behavior tree karena peneliti menginginkan behavior tertentu. Parameter yang banyak dan kompleks pada strategi bertarung Dude Knight dapat diatasi dengan baik menggunakan Utility Al.

\section{Metode Penelitian}

Sebelum beranjak ke rancangan pembuatan auto-battle menggunakan utility Al, mula-mula perlu diketahui cara kerja skill di game Dude Knight. Kemudian performa auto-battle bawaan beserta perilaku yang ingin dicapai berdasarkan analisa tersebut.

\subsection{Skill yang Digunakan di Game Dude Knight}

Dude Knight memiliki sebanyak 123 skill termasuk aksi attack, guard, dan escape. Skill pada game ini memiliki banyak atribut seperti nama, icon, deskripsi, formula, efek, skill type atau golongan skill, dll. Namun hanya ada 12 atribut yang dapat mempengaruhi strategi. Atribut tersebut dapat dilihat pada Tabel 1.

Tabel 1. Atribut Pada Setiap Skill yang Dapat Mempengaruhi Strategi

\begin{tabular}{ccc}
\hline No & Atribut & Deskripsi \\
\hline 1 & $\begin{array}{c}\text { Damage } \\
\text { Type }\end{array}$ & $\begin{array}{c}\text { Tipe kerusakan. Tipe tersebut adalah HP Damage, HP } \\
\text { Recover, MP Recover, HP Drain, MP drain, dan None. }\end{array}$ \\
\hline & $\begin{array}{c}\text { Jenis element. Element tersebut adalah normal, none, } \\
\text { physical, absorb, fire, ice, thunder, water, earth, wind, holy, } \\
\text { dan dark. Beberapa musuh kebal terhadap satu atau lebih } \\
\text { element. Perhitungan element dilakukan setelah perhitungan }\end{array}$
\end{tabular}
formula. 


\begin{tabular}{|c|c|c|}
\hline 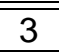 & Formula & Perhitungan damage mula-mula yang akan dihasilkan \\
\hline 4 & Variance & $\begin{array}{l}\text { Mencegah menghasilkan damage yang sama setiap kali } \\
\text { menggunakan skill. Variasi damage dihitung terakhir setelah } \\
\text { formula dan element. }\end{array}$ \\
\hline 5 & Critcal & $\begin{array}{c}\text { Bersifat boolean. Critical adalah kondisi khusus dimana suatu } \\
\text { serangan menghasilkan beberapa persen }(>=50 \%) \text { lebih } \\
\text { besar dari biasanya. Kemungkinan kondisi ini terjadi dan } \\
\text { besarnya tambahan kerusakan berbeda-beda untuk tiap } \\
\text { karakter. }\end{array}$ \\
\hline 6 & Cost & $\begin{array}{r}\text { (TP/MP) Biaya yang dibutuhkan } \mathrm{r} \\
\text { skill. }\end{array}$ \\
\hline 7 & Scope & $\begin{array}{l}\text { Target area yang dipengaruhi. Target tersebut adalah none, } \\
\text { one enemy, all enemies, } 1 \text { random enemy, } 2 \text { random } \\
\text { enemies, } 3 \text { random enemies, } 4 \text { random enemies, one ally, all } \\
\text { allies, one ally (dead), all allies (dead), dan the user. }\end{array}$ \\
\hline 8 & Effect & Efek-efek yang ditimbulkan selain damage. \\
\hline 9 & Speed & Waktu yang dibutuhkan untuk melancarkan suatu serangan \\
\hline 10 & $\begin{array}{c}\text { Success } \\
\text { Rate }\end{array}$ & Tingkat kesuksesan suatu serangan mengenai targetnya \\
\hline 11 & Repeats & Jumle \\
\hline 12 & $T$ & $\begin{array}{l}\text { Bersifat boolean. Memberikan sejumlah TP jika mengenai } \\
\text { target. }\end{array}$ \\
\hline
\end{tabular}

\subsection{Perilaku yang Ingin Dicapai untuk Auto-Battle Utility AI}

Penentuan perilaku auto-battle yang baru bisa dilihat kembali ke alasan diciptakannya auto-battle, yaitu mengatasi permasalahan grinding untuk pemain yang memiliki waktu terbatas atau sedikit untuk bermain. Sehingga, perilaku yang diharapkan untuk auto-battle yang baru adalah sebagai berikut:

a. Tidak mudah kalah. Kekalahan akan mengakibatkan game over dan progress akan kembali ke titik penyimpanan sebelumnya. Bisa dikatakan grinding yang dilakukan akan sia-sia.

b. Dapat menyelesaikan setiap pertarungan dengan cepat, karena pemain sendiri tidak memiliki banyak waktu.

\subsection{Pembagian Atribut}

12 Atribut yang mempengaruhi strategi pada setiap skill akan dibagi menjadi dua jenis. Jenis pertama adalah yang nilai utility-nya tidak terpengaruh oleh kondisi pertarungan pada saat itu. Sehingga, atribut-atribut ini akan memiliki nilai utility yang tetap setiap saat. Sebut saja atribut tersebut memiliki static utility atau nilai utilitas tetap. Atribut-atribut dengan static utility adalah variance, critical, speed, success rate, dan repeat.

Sedangkan atribut yang perhitungan utility-nya menyesuaikan kondisi pertarungan pada saat itu disebut memiliki dynamic utility atau nilai utilitas dinamis. Atribut dengan dynamic utility adalah damage type, formula, element, cost, scope, effect, dan TP Gain. Pembagian atribut ini dilakukan hanya untuk memudahkan implementasi dan debugging terhadap perilaku yang dihasilkan apakah sudah sesuai dengan yang diharapkan atau belum. Selain itu, pembagian atribut ini dilakukan untuk menentukkan atribut apa yang memiliki pengaruh besar dan atribut apa yang memiliki pengaruh kecil dalam penentuan strategi. Atribut dengan dynamic utility memiliki pengaruh besar dalam penentuan strategi, sehingga perlu dicari rumus perhitungan nilai utility yang sesuai dengan rancangan. Pengembang dapat menggunakan rumus apapun untuk menciptakan perilakunya. Rumus tersebut bisa berupa grafik linier, kuadratik, atau eksponensial[8].

\subsection{Perhitungan Nilai Utilitas untuk Setiap Atribut}

a. Variance

Variance yang terlalu rendah akan membuat damage yang dihasilkan cenderung stagnan atau tidak banyak perubahan. Sedangkan variance yang terlalu tinggi akan membuat damage tidak konsisten. Maka dari itu diambil nilai pertengahan yaitu 20-30. Nilai variance di luar jarak 
tersebut tidak akan memiliki nilai utilitas. Sedangkan jika masuk dalam jarak tersebut akan mendapat penambahan utilitas sebesar 0.015 .

b. Critical

Jika nilai critical pada suatu skill adalah false, maka tidak mendapatkan tambahan utilitas.

Sedangkan jika true, maka nilai utilitasnya akan bertambah sebesar 0.05 .

c. Speed

Rata-rata skill dalam game Dude Knight memiliki speed sebesar 0. Beberapa memiliki speed 1000 dan 2000 agar skill tersebut adalah yang pertama dilancarkan dalam suatu giliran. Terdapat satu skill dengan nilai speed 100. Skill ini memang lebih cepat dari pada skill pada umumnya, namun tidak didesain untuk dilancarkan pertama kali dalam suatu giliran. Sisanya memiliki speed sekitar -5 hingga -40 . Maka dari itu hanya speed dibawah 101 yang akan memiliki perubahan nilai utilitas dengan perhitungan seperti pada Persamaan 1.

$$
\frac{\text { speed }}{2000}
$$

\section{d. Success Rate}

Tidak ada skill yang memiliki success rate di atas $100 \%$, sehingga nilai utilitas untuk skill dengan success rate di bawah 100\% akan berkurang sebesar hasil dari Persamaan 2.

$$
\frac{100-\text { success rate }}{1000}
$$

e. Repeats

Setiap kelipatan repeats dalam suatu skill (kecuali kelipatan satu), nilai utilitasnya akan bertambah sebesar 0.025 .

f. Damage Type

Setiap jenis damage type memiliki cara pertihungan nilai utilitas yang berbeda. Tipe kerusakan beserta penyebab dan perhitungannya dapat dilihat pada Tabel 2.

Tabel 2. Perhitungan Nilai Utilitas Dari Atribut Damage Type

\begin{tabular}{ccc}
\hline Damage Type & Penyebab & Modifier \\
\hline HP Damage & Jumlah musuh yang masih hidup & $\times 0.25$ \\
& Setiap teman yang memiliki HP di & $\left(e^{-h p \text { rate }}\right)^{*}$ \\
bP Recover & bawah 85\% & $\times 0.05$ \\
MP Recover & Jumlah musuh yang masih hidup & $\left(e^{-2(\text { mp rate })}\right)^{*}$ \\
HP Drain & HP pengguna & $\left(e^{-2(\text { h r rate })}\right)^{*}$ \\
& Jumlah musuh yang masih hidup & $\times 0.05$ \\
MP Drain & MP pengguna & $\left(e^{-2(\text { mp rate })}\right)^{*}$ \\
& Jumlah musuh yang masih hidup & $\times 0.05$
\end{tabular}

*hp rate didapat dari hp saat itu dibagi maksimum hp suatu karakter. Hal yang sama juga berlaku untuk $\mathrm{mp}$ rate

\section{g. Formula}

Hasil perhitungan damage dari formula tidak langsung dikonversikan ke dalam nilai utilitas, melainkan diolah lagi oleh atribut element. Namun untuk skill jenis penyembuhan, akan dihitungan efektifitasnya. Maksud dari efektifas penyembuhan adalah tingkat kesamaan $h p$ yang bisa disembuhkan dalam satu kali penggunaan skill penyembuhan dengan $h p$ yang hilang pada suatu karakter. Jika sudah melalui perhitungan element atau efektifitas, maka nilai utilitasnya bisa didapat melalui Persamaan 3.

$$
\frac{(\text { formula/100) }}{\text { level pengguna }}
$$


h. Element

Atribut element tidak menghasilkan nilai utilitas, namun tetap bisa mempengaruhi nilai utilitas dari atribut formula. Suatu musuh memiliki fitur yang disebut element rate yang berarti daya tahan terhadap suatu element. Musuh tidak lemah maupun tidak tahan terhadap suatu element jika memiliki element rate $100 \%$. Contoh suatu musuh memiliki fitur element rate [fire] $200 \%$, maka skill dengan element api akan menghasilkan kerusakan dua kali lebih banyak.

i. Cost

Nilai utilitas dari TP Cost didapat melalui Persamaan 4. Sedangkan nilai utilitas dari MP Cost didapat melalui Persamaan 5.

$$
\begin{aligned}
& e^{-\frac{t p-t p \cdot \cos t}{4}}+0.15 \\
& \frac{m p-m p \cos t}{\max m p} \times 0.3
\end{aligned}
$$

\section{j. Scope}

Atribut ini adalah atribut terakhir yang dihitung, karena melalui atribut ini, target akan dipilih. Scope hanya merubah nilai utilitas yang didapat dari atribut formula. Nilai utilitas formula akan dikali sejumlah musuh yang ada jika skill yang digunakan menarget semua musuh. Jika hanya satu musuh, maka akan dicari target dengan nilai utilitas paling tinggi.

\section{k. Effects}

Penentuan nilai utilitas effect dihitung dari banyaknya musuh yang belum terkena effect yang dihasilkan suatu skill dan musuh yang tidak memiliki ketahanan pada effect tersebut.

I. TP Gain

Nilai utilitas bertambah sebesar 0.025 setiap TP yang didapat.

\subsection{Perhitungan Nilai Utilitas untuk Effect}

Dude Knight memiliki tujuh jenis status effects. Status effects tersebut adalah poison, blind, silence, confusion, sleep, dan paralyze. Menurut kegunaannya, keenam efek tersebut dapat dibagi menjadi dua tipe, yaitu efek perusak dan efek pelumpuh.

\section{a. Efek Perusak}

Status effect yang tergolong efek perusak adalah poison dan confusion. Poison akan memberikan kerusakan setiap giliran tergantung maksimal hp yang dimiliki penderita. Confusion akan mengakibatkan penderita berkemungkinan menyerang diri sendiri atau teman. Efek jenis ini efektif digunakan pada musuh dengan tingkat $h p$ yang tinggi. Penentuan nilai utilitas untuk jenis efek perusak didapat melalui Persamaan 6.

$$
\frac{\text { hp rate musuh }}{10}
$$

Musuh yang sudah menderita efek yang sama dan musuh yang kebal terhadap efek tersebut tidak akan dihitung.

\section{b. Efek Pelumpuh}

Status effect yang tergolong efek pelumpuh adalah blind, silence, sleep, dan paralyze. Blind mengakibatkan penderita tidak bisa membidik target dengan baik. Namun serangan magic tidak terpengaruh. Silence mengakibatkan penderita tidak bisa menggunakan serangan magic. Sleep mengakibatkan penderita tidur sehingga tidak bisa melancarkan serangan apapun. Namun jika penderita menerima kerusakan, efek sleep akan langsung hilang. Sedangkan paralyze mengakibatkan penderita berkemungkinan gagal melancarkan aksinya. Efek jenis ini efektif digunakan ketika terdapat banyak musuh. Penentuan nilai utilitas untuk jenis efek pelumpuh didapat dari Persamaan 7.

$$
\frac{\text { jumlah musuh yang tidak terpengaruh }}{20}
$$


Musuh yang tidak terpengaruh maksudnya adalah musuh yang tidak sedang menderita efek yang akan diberikan beserta musuh yang kebal terhadap efek tersebut.

\subsection{Perhitungan Nilai Utilitas untuk Beberapa Skill Khusus}

Terdapat beberapa skill yang memiliki perhitungan nilai utilitas sendiri dikarenakan skill tersebut berguna untuk disituasi tertentu. Skill tersebut adalah:

a. Guard

Guard akan mengurangi kerusakan yang diterima sebanyak 50\%. Skill ini baik digunakan untuk karakter yang kondisi $h p$ tinggal sedikit. Perhitungan nilai utilitas untuk skill ini adalah jika $h p$ karakter dibawah $25 \%$, maka nilai utilitas bertambah 1.25 .

b. Cure I

Cure I dapat menghilangkan status effect poison dan paraylsis yang diderita suatu karakter. Sehingga setiap terdapat karakter yang menderita kedua efek tersebut, maka nilai utilitas akan bertambah sebesar 3.1

c. Cure II

Cure I/ dapat menghilangkan segala jenis status effect yang diderita suatu karakter. Sehingga setiap terdapat karakter yang menderita efek selain poison dan paralysis, maka nilai utilitas akan bertambah sebesar 3.2. Sedangkan setiap karakter yang menderita poison dan paralyis, maka nilai utilitas akan bertambah sebesar 3. Cure I \& I/ mendapat penambahan nilai utilitas yang tinggi agar penyembuhan status effect menjadi prioritas utama.

d. Raise I \& II

Raise I \& // dapat menghidupkan kembali karakter yang telah gugur. Namun hp karakter yang dihidupkan hanya kembali beberap persen. Perbedaannya terletak pada raise /I dapat mengembalikan $h p$ lebih banyak ketika menghidupkan teman. Jika terdapat teman yang gugur, maka nilai utilitas akan bertambah 3.5 untuk raise I dan 3.6 untuk raise II.

e. Provoke

Provoke akan mengakibatkan musuh cenderung menyerang karakter yang menggunakan skill ini. Provoke sangat bermanfaat ketika terdapat teman yang hampir gugur, sehingga musuh tidak akan menyerang teman tersebut. Nilai utilitas untuk skill ini bertambah sebesar 0.3 setiap teman dengan $h p$ dibawah $50 \%$.

\subsection{Pengujian}

Pengujian yang dilakukan hanyalah performa auto-battle Utility Al ketika bertarung. Pengaruh auto-battle terhadap kesenangan ketika bermain tidak perlu diuji. Jika menggunakan taksonomi milik Bartle, pemain dengan kategori explorers lebih tertarik dengan meningkatkan kemampuan untuk mengeksplorasi dunia yang ditawarkan di game. Beberapa pemain juga merasakan kesenangan ketika melihat karakter yang mereka mainkan di dalam game menggunakan benda yang kuat yang didapat dari mengalahkan musuh[9].

Terdapat dua jenis pengujian untuk mengetahui performa auto-battle Utility Al. Pertama, baik auto-battle bawaan maupun auto-battle Utility Al akan dilakukan simulasi pertarungan melawan setiap troops dalam game. Troops adalah kombinasi musuh yang akan muncul untuk dilawan oleh pemain. Pada game Dude Knight, tidak ada lebih dari satu jenis musuh dalam satu troops. Melainkan suatu troops hanya terdiri dari satu jenis musuh sebanyak 1 hingga 3 unit. Empat dari karakter game akan dipilih untuk bertarung sebagai tim melawan troops tersebut. Tim karakter tersebut sama untuk semua pengujian dan untuk kedua Al. Setiap troops yang dilawan akan dilakukan pengujian sebanyak 30 kali. Data dari pengujian tersebut akan akan dibandingkan. Data yang akan dibandingkan adalah sebagai berikut

1. Menang atau kalah

2. Jumlah turn atau giliran yang dibutuhkan untuk menyelesaikan pertarungan, baik menang maupun kalah

Pengujian kedua adalah simulasi pertarungan langsung antar kedua AI. Setiap unit dari kedua kubu dibuat sama baik dari tingkat kekuatan maupun skill yang dimiliki. Simulasi pertarungan akan dilakukan sebanyak 30 kali. Data yang diambil hanya rasio kemenangan, kekalahan, dan jumlah giliran yang dibutuhkan untuk menyelesaikan pertarungan, baik menang maupun kalah.

Khusus untuk pengujian pertama, data yang didapat akan dilakukan t-test untuk mengetahui adanya perbedaan signifikan antar kedua Al ketika melawan suatu troops[10]. Jika ketika melawan suatu troops terbukti adanya perbedaan signifikan, barulah akan dibandingkan

REPOSITOR, Vol. 2, No. 3, Maret 2020: 277-286 
AI mana yang memiliki rasio kemenangan lebih tinggi dan giliran yang dibutuhkan untuk menang lebih cepat. Adanya status effect dan critical yang sangat berhubungan dengan peluang akan membuat data yang didapat bisa bervariasi. Maka dari itu, level signifikansi( $\alpha$ ) yang digunakan untuk t-test adalah 0.025 .

Dude Knight memiliki 10 karakter dan 9 jenis class. Class inilah yang menentukkan peran suatu karakter dalam pertarungan. Class ini pula yang menentukan skill yang akan diterima suatu karakter ketika mencapai level yang dibutuhkan. Namun dalam pertarungan, hanya ada 4 karakter yang dapat digunakan. Maka dipilihlah 4 karakter dengan class berbeda atau peran yang dapat menyeimbangkan tim. Peran tersebut adalah peran yang umum digunakan pada game RPG, yaitu damage dealer, tanker, dan support/healer. Sehingga, class yang dipilih adalah Soldier, Priestess, Paladin, dan Witch. Tim dengan kombinasi class ini akan digunakan di setiap simulasi pertarungan. Terdapat sebanyak 28 kombinasi musuh (troops) bukan tergolong boss yang dapat dihadapi pemain selama bermain. Sehingga terdapat 840 simulasi pertarungan untuk setiap Al.

\section{Hasil dan Diskusi}

\subsection{Hasil Pertarungan Melawan Troops}

Dari hasil simulasi pertarungan yang dilakukan, kedua Al memiliki rasio kemenangan $100 \%$ untuk setiap troops kecuali ketika melawan Sahagin. Ketika melawan Sahagin, kedua AI mengalami kekalahan sebanyak 2 kali dari 30 pertarungan. Sedangkan dari hasil t-test melawan 28 troops, 14 diantaranya terbukti tidak ada perbedaan signifikan, dan 14 sisanya terbukti terdapat perbedaan yang signifikan. Setelah mengetahui troops mana yang terbukti adanya perbedaan, langkah selanjutnya adalah melakukan perbandingan antar kedua Al melawan 14 troops dimana perbedaan telah terbukti tersebut.

Tabel 3. Rata-rata Giliran yang Dibutuhkan Untuk Menang Pada Kedua Al

\begin{tabular}{|c|c|c|c|}
\hline No & Troops & Jenis Al & Rata-rata turn \\
\hline \multirow{2}{*}{1} & \multirow{2}{*}{ Rate } & Original & 2.767 \\
\hline & & Utility AI & 2.467 \\
\hline \multirow{2}{*}{2} & \multirow{2}{*}{ Wisp } & Original & 3.567 \\
\hline & & Utility $\mathrm{Al}$ & 3.000 \\
\hline \multirow{2}{*}{3} & \multirow{2}{*}{ Scorpion } & Original & 3.867 \\
\hline & & Utility Al & 3.467 \\
\hline \multirow{2}{*}{4} & \multirow{2}{*}{ Gazer } & Original & 5.067 \\
\hline & & Utility Al & 3.933 \\
\hline \multirow{2}{*}{5} & \multirow{2}{*}{ Puppet } & Original & 2.367 \\
\hline & & Utility Al & 2.000 \\
\hline \multirow{2}{*}{6} & \multirow{2}{*}{ Cockatrice } & Original & 3.267 \\
\hline & & Utility Al & 2.433 \\
\hline \multirow{2}{*}{7} & \multirow{2}{*}{ Mimic } & Original & 2.933 \\
\hline & & Utility Al & 2.267 \\
\hline \multirow{2}{*}{8} & \multirow{2}{*}{ Werewolf } & Original & 4.967 \\
\hline & & Utility AI & 3.567 \\
\hline \multirow{2}{*}{9} & \multirow{2}{*}{ Ogre } & Original & 2.867 \\
\hline & & Utility Al & 2.033 \\
\hline \multirow{2}{*}{10} & \multirow{2}{*}{ Gargoyle } & Original & 8.167 \\
\hline & & Utility AI & 5.533 \\
\hline \multirow{2}{*}{11} & \multirow{2}{*}{ Lamia } & Original & 7.433 \\
\hline & & Utility AI & 3.900 \\
\hline \multirow{2}{*}{12} & \multirow{2}{*}{ Vampire } & Original & 5.167 \\
\hline & & Utility AI & 3.967 \\
\hline \multirow{2}{*}{13} & \multirow{2}{*}{ Succubus } & Original & 27.933 \\
\hline & & Utility Al & 16.467 \\
\hline \multirow{2}{*}{14} & \multirow{2}{*}{ Demon } & Original & 10.067 \\
\hline & & Utility AI & 6.533 \\
\hline
\end{tabular}


Dari setiap troops pada Tabel 3, auto-battle menggunakan Utility AI memiliki rata-rata giliran yang dibutuhkan untuk menang lebih kecil dari auto-battle bawaan. Hal ini menunjukkan bahwa auto-battle Utility Al dapat memenangkan pertarungan lebih cepat dari pada auto-battle bawaan.

\subsection{Hasil Pertarungan Antara Utility Al dengan Al Bawaan}

Pada Tabel 4, dapat dilihat bahwa Utility Al memenangkan 26 dari 30 pertarungan atas $\mathrm{Al}$ bawaan. Jumlah giliran yang dibutuhkan oleh Utility Al untuk menang juga lebih cepat dari pada jumlah giliran yang dibutuhkan untuk kalah.

Tabel 4 Hasil Pengujian Auto-Battle Utility Al Melawan Auto-Battle Bawaan

\begin{tabular}{|c|c|c|}
\hline Pengujian ke & Pemenang & Jumlah giliran \\
\hline 1 & Utility Al & 10 \\
\hline 2 & Utility AI & 5 \\
\hline 3 & Utility AI & 6 \\
\hline 4 & Utility AI & 10 \\
\hline 5 & Utility AI & 6 \\
\hline 6 & Utility AI & 6 \\
\hline 7 & Utility AI & 7 \\
\hline 8 & Utility AI & 8 \\
\hline 9 & Utility AI & 8 \\
\hline 10 & Utility AI & 7 \\
\hline 11 & Original & 6 \\
\hline 12 & Utility Al & 6 \\
\hline 13 & Utility AI & 7 \\
\hline 14 & Utility AI & 7 \\
\hline 15 & Utility AI & 6 \\
\hline 16 & Utility AI & 5 \\
\hline 17 & Original & 6 \\
\hline 18 & Utility AI & 6 \\
\hline 19 & Original & 7 \\
\hline 20 & Utility Al & 9 \\
\hline 21 & Original & 12 \\
\hline 22 & Utility Al & 7 \\
\hline 23 & Utility AI & 10 \\
\hline 24 & Utility Al & 7 \\
\hline 25 & Utility AI & 8 \\
\hline 26 & Utility AI & 8 \\
\hline 27 & Utility AI & 7 \\
\hline 28 & Utility AI & 7 \\
\hline 29 & Utility AI & 8 \\
\hline 30 & Utility AI & 6 \\
\hline \multirow{2}{*}{ Rata-rata } & Turn (Utility Al) & 7.192308 \\
\hline & Turn (Original) & 7.75 \\
\hline
\end{tabular}

\section{Kesimpulan}

Berdasarkan hasil pengujian yang telah dilakukan dapat disimpulkan bahwa fitur autobattle menggunakan Utility AI telah berhasil dibuat. Pengujian auto-battle dapat dilakukan dengan membandingkan auto-battle bawaan Dude Knight dengan auto-battle Utility Al yang telah dibuat. Hasil pengujian pertama adalah auto-battle Utility Al dan auto-battle bawaan memiliki rasio kemenangan yang sama untuk setiap troops yang dilawan yaitu sebanyak 27 dari 28 troops, dengan rasio kemenagan $100 \%$. Sedangkan satu troops sisanya, kedua Al memiliki rasio kemenangan $93 \%$. Hasil t-test dari pengujian pertama adalah 14 dari 28 troops yang dilawan memiliki $p$-value dibawah level signifikansi $(\alpha=0.025)$ yang berarti perbedaan yang terjadi pada 14 troops tersebut bukan karena kebetulan. Pada 14 troops tersebut, auto-battle Utility Al memenangkan pertarungan lebih cepat dibandingkan auto-battle bawaan. Hasil pengujian kedua adalah auto-battle Utility AI memenangkan 26 dari 30 pertarungan melawan auto-battle bawaan. 
Sehingga bisa disimpulkan bahwa auto-battle Utility AI memiliki kemenangan yang lebih stabil dan memenangkan pertarungan lebih cepat seperti yang sudah diharapkan.

\section{Referensi}

[1] F. Mayra, An Introduction to Game Studies - Games in Culture. London: SAGE Publications, 2008.

[2] Entertainment Software Association, "2017 Essential Facts About The Computer And Video Game Industry," 2017.

[3] S. Fizek, "The work of game in the age of automation," Gaming and Virtual Worlds, pp. 197201, 2018.

[4] D. Mark, Behavioral Mathematics For Game Al. Boston: Course Technology, 2009.

[5] M. N. M. Othman and H. Haron, "Implementing game artificial intelligence to decision making of agents in emergency egress," 2014 8th Malaysian Softw. Eng. Conf. MySEC 2014, pp. 316-320, 2014.

[6] K. Dill, "A Game Al Approach to Autonomous Control of Virtual Characters A Game Al Approach to Autonomous Control of Virtual Characters," Interservice/Industry Training, Simulation, Educ. Conf., no. 11136, pp. 1-11, 2011.

[7] S. Jadon, A. Singhal, and S. Dawn, "Military Simulator -A Case Study of Behaviour Tree and Unity based architecture," Int. J. Comput. Appl., vol. 88, no. 5, pp. 26-29, 2014.

[8] D. Mark and K. Dill, "Improving Al Decision Modeling Through Utility Theory," in Al Summit GDC 2010, 2010.

[9] H. Wang and C.-T. Sun, "Game Reward Systems: Gaming Experiences and Social Meanings," in Proceedings of DiGRA 2011 Conference: Think Design Play, 2011.

[10] S. Boslaugh and P. A. Watters, Statistics in a Nutshell: A Desktop Quick Reference, 1st ed. Sebastopol: O'Reilly Media, 2008. 
REPOSITOR, Vol. 2, No. 3, Maret 2020: 277-286 